\title{
Esophageal Sensation and Esophageal Hypersensitivity - Overview From Bench to Bedside
}

\author{
Hiroto Miwa, MD, PhD*, Takashi Kondo, MD, Tadayuki Oshima, MD, Hirokazu Fukui, MD, Toshihiko Tomita, MD \\ and Jiro Watari, MD
}

Division of Upper Gastroenterology, Department of Internal Medicine, Hyogo College of Medicine, Hyogo, Japan

Noxious stimuli in the esophagus activate nociceptive receptors on esophageal mucosa, such as transient receptor potential, acid-sensing ion channel and the P2X family, a family of ligand-gated ion channels responsive to ATP, and this generates signals that are transmitted to the central nervous system via either spinal nerves or vagal nerves, resulting in esophageal sensation. Among the noxious stimuli, gastric acid and other gastric contents are clinically most important, causing typical reflux symptoms such as heartburn and regurgitation. A conventional acid penetration theory has been used to explain the mechanism of heartburn, but much recent evidence does not support this theory. Therefore, it may be necessary to approach the causes of heartburn symptoms from a new conceptual framework. Hypersensitivity of the esophagus, like that of other visceral organs, includes peripheral, central and probably psychosocial factor-mediated hypersensitivity, and is known to play crucial roles in the pathoegenesis of nonerosive reflux disease, functional heartburn and non-cardiac chest pain. There also are esophagitis patients who do not perceive typical symptoms. This condition is known as silent gastroesophageal reflux disease. Although the pathogenesis of silent gastroesophageal reflux disease is still not known, hyposensitivity to reflux of acid may possibly explain the condition.

(J Neurogastroenterol Motil 2010;16:353-362)

Key Words

Gastroesophageal reflux; Heartburn; Hypersensitivity; Hyposensitivity; Pain receptor

\section{Introduction}

Although assessment of symptoms is a part of the foundation of clinical medicine, the mechanisms of symptom manifestation have not been adequately elucidated, especially in the cases of abdominal symptoms, which are often extremely vague and dull. As symbolized by the concept of referred pain, the site where visceral pain originates often cannot be inferred from the site where it is felt. ${ }^{1}$ While there is a great need to better understand visceral symptoms, their study is difficult for a number of reasons. The responses of individuals to stimuli are highly diverse, with the same stimulus not necessarily producing the same symptom in different individuals; the severity of symptoms is difficult to

Received: July 2, 2010 Revised: August 13, 2010 Accepted: August 19, 2010

(c) This is an Open Access article distributed under the terms of the Creative Commons Attribution Non-Commercial License (http://creativecommons. org/licenses/by-nc/3.0) which permits unrestricted non-commercial use, distribution, and reproduction in any medium, provided the original work is properly cited.

*Correspondence: Hiroto Miwa, MD, PhD

Division of Upper Gastroenterology, Department of Internal Medicine, Hyogo College of Medicine, 1-1 Mukogawa-cho, Nishinomiya, Hyogo 663-8501, Japan

Tel: +81-798-45-6662, Fax: +81-798-45-6661, E-mail: miwahgi@hyo-med.ac.jp

Financial support: The Grant-in-aid for scientific research, Japan (21590799).

Conflicts of interest: None. 
quantify; and patients do not necessarily use the same words to describe the same sensations. As a site for research on visceral sensation, the esophagus offers a number of advantages; for example, determination of the sites where esophageal symptoms originate is comparatively easy, and the esophagus has the comparatively specific symptom heartburn. However, even in the esophagus, research on the manifestation of symptoms is not easy. In this article, we review findings related to esophageal sensation and hypersensitivity in the hope of contributing to the understanding of the mechanisms by which visceral symptoms are manifested.

\section{Basis of Esophageal Sensation Pathway -}

After being swallowed, food and beverages are automatically conveyed to the stomach through the esophagus. Normally, this process occurs unconsciously, but if the food or beverage is excessively hot or cold, the person will perceive the process. Furthermore, when a large amount of material is swallowed, pain

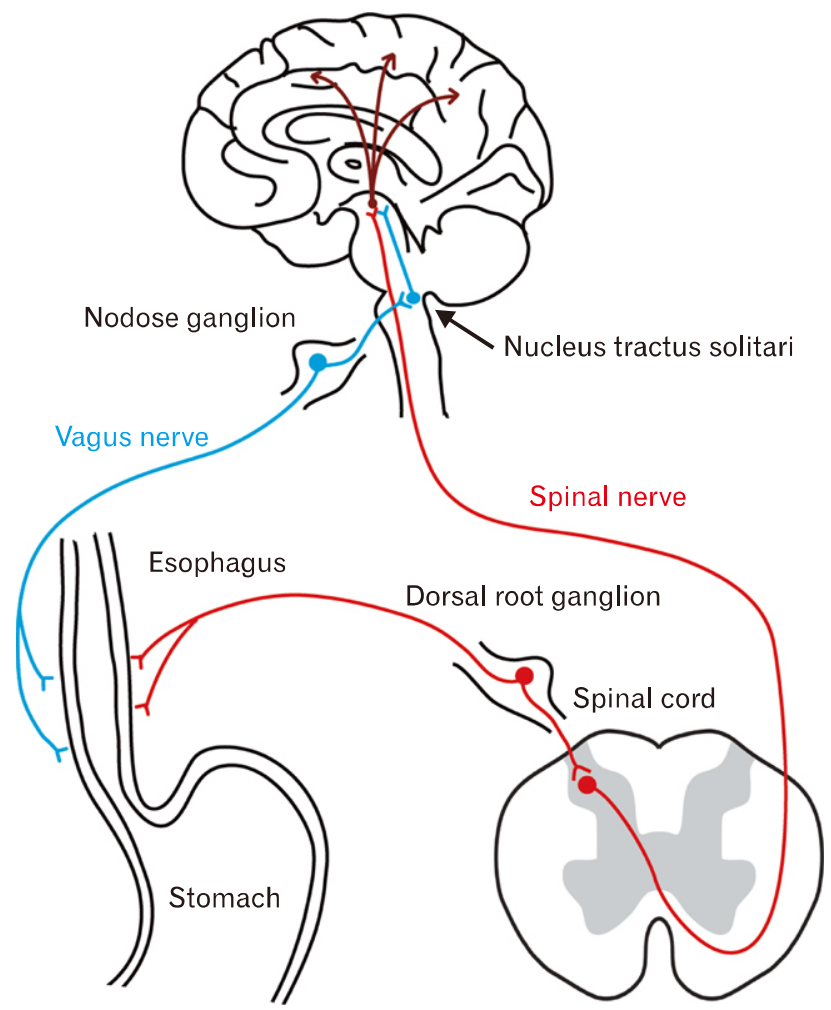

Figure 1. Sensory pathway from esophagus to brain. Esophageal nociceptive stimuli are conveyed to the brain via 2 major sensory pathways - a sympathetic pathway and vagal pathway. is felt. These are esophageal sensations. A substantial amount of knowledge has accumulated about the stimuli responsible for such sensations, the pathways by which those stimuli are transmitted to the central nervous system, and the receptors that mediate that transmission.

It is thought that, generally, noxious stimuli - chemical, mechanical, thermal and etc - in the esophageal mucosa are converted to action potentials by nociceptive receptors on esophageal nerves and are then transmitted to the central nervous system via either spinal nerves or vagal nerves (Fig. 1). Via the spinal nerve pathway, the signals are transmitted to laminae I and II of the dorsal horn of the spinal cord via dorsal root ganglia, where the cell bodies of the primary sensory neurons are located. Noxious information arriving at the dorsal horn is then transmitted to secondary neurons by neurotransmitter-mediated synaptic transmission, and then directly or interneuronally transmitted to the thalamus. The axons of the dorsal horn neurons involved in transmission to the thalamus are thought to ascend the spinothalamic tract in the contralateral lateral funiculus. ${ }^{2-4}$ The vagus nerves are also thought to play an important role in communication between the gastrointestinal (GI) tract and brain. In the vagal pathway, noxious information is thought to be transmitted to the nucleus of the solitary tract via the nodose ganglia. ${ }^{2-4}$ While the significance of these two sensory pathways is still not well understood, it is possible that a specific transmission pathway may be selected depending upon the type of noxious stimulus, as specific receptors are associated with different types of noxious stimuli. In the stomach, vagus and spinal nerves have been shown to be involved in transmission of signals from chemical and mechanical stimuli, respectively, ${ }^{5-7}$ while in the esophagus, it has been inferred that perception of noxious stimuli involves mainly spinal nerves. $^{8}$

Identification of the receptors for noxious stimuli is essential for understanding esophageal sensation and hypersensitivity. In the field of somatic pain, proteins and receptors expressed specifically in primary sensory neurons have been discovered one after another, and their roles in the transmission of pain sensation are being investigated. Receptors of the transient receptor potential (TRP) cation channel family are typical. ${ }^{9}$ The TRP family consists of six subfamilies, each of which has additional unique channels. Many other nociceptive receptors, including those of the acid-sensing ion channel (ASIC) family and the P2X family, a family of ligand-gated ion channels responsive to ATP, have been cloned, but in regard to the esophagus, the transient receptor potential vanilloid 1 (TRPV1) receptor has attracted the 
most attention. This receptor, which is highly expressed in sensory neurons in the GI, is the first molecule involved in the transduction of external thermal stimuli to electrical excitation in the nervous system to be discovered. ${ }^{10,11}$ In an analysis in TRPV1 knockout mice, vagal action potentials in response to mechanical stimulation of the esophagus were weaker in the knockout animals than in the wild-type animals, ${ }^{12}$ showing that TRPV1 plays an important role in the response to mechanical stimulation. Other findings have shown that TRPV1 is involved in the response to acid; those include the finding that acid-induced esophagitis was suppressed in TRPV1 knockout mice compared to wild type mice ${ }^{13}$ and the finding that expression of receptors in dorsal root ganglia was increased in rats whose esophagus had been exposed to acid. ${ }^{14}$ TRPV1 is also said to be involved in neurogenic symptoms that are accompanied by peripheral release of substance $\mathrm{P}$ and calcitonin gene-related peptide. ${ }^{15,16}$

Transient receptor potential A1 (TRPA1), a member of the TRP channel family that is thought to be a receptor for cold stimuli, is also known to be involved in esophageal sensation. When guinea pig esophagus was treated with bradykinin (chemical stimulation), TRPA1 in vagal C fibers was involved in the sensory pathway. ${ }^{17}$ We reported that TRPA1 mediated perception of gastric distention in rats, ${ }^{18}$ and this receptor may also be involved in perception of esophageal distention. In addition, it has been reported that the ATP cation channel receptor P2X is involved in perception of gastric distention ${ }^{19-21}$ and other studies have shown that proton-sensitive ASICs are related to sensation of gastric distension and acid. ${ }^{12,22}$ Table 1 lists the peripheral receptors for noxious esophageal stimuli and the associated pathways to the central nervous system that have been reported so far. ${ }^{8,12-14,17,19-33}$

Table 1. Peripheral Receptors for Mechanical or Chemical Stimulation of Esophagus

\begin{tabular}{|c|c|c|c|c|c|}
\hline $\begin{array}{l}\text { Stimulation } \\
\text { category }\end{array}$ & Receptor & $\begin{array}{l}\text { Experimental } \\
\text { species }\end{array}$ & Investigated nerves & Stimulation details & References \\
\hline \multirow[t]{16}{*}{ Mechanical } & \multirow[t]{2}{*}{ TRPV1 } & $\begin{array}{l}\mathrm{TRPV}^{-/-} \\
\text {mouse }\end{array}$ & $\begin{array}{l}\text { Gastro-esophageal vagal afferent } \\
\text { nerve }\end{array}$ & Mechanical distension & $\begin{array}{l}\text { Bielefeldt and Davis, } \\
2008\end{array}$ \\
\hline & & Rat & Thoracic spinal neurons & $\begin{array}{l}\mathrm{HCl} \text {, Capsaicin }+ \text { Esophageal } \\
\text { distension }\end{array}$ & Qin et $a{ }^{8}, 2008$ \\
\hline & TRPA1 & Guinea pig & Esophageal vagal afferent nerve & Mechanical distension & Yu and Ouyang, ${ }^{17} 2009$ \\
\hline & ASIC 3 & $\begin{array}{l}\mathrm{ASIC}^{-/-} \\
\text {mouse }\end{array}$ & $\begin{array}{l}\text { Gastro-esophageal vagal afferent } \\
\text { nerve }\end{array}$ & Mechanical distension & $\begin{array}{l}\text { Bielefeldt and Davis, } \\
2008\end{array}$ \\
\hline & ASIC 1 & $\begin{array}{l}\mathrm{ASIC}^{-/-} \\
\text {mouse }\end{array}$ & $\begin{array}{l}\text { Gastro-esophageal vagal afferent } \\
\text { nerve }\end{array}$ & $\begin{array}{l}\text { Circumferential tension, } \\
\text { mucosal stroking }\end{array}$ & Page et al, 22005 \\
\hline & ASIC2 & $\begin{array}{l}\mathrm{ASIC}^{-/-} \\
\text {mouse }\end{array}$ & $\begin{array}{l}\text { Gastro-esophageal vagal afferent } \\
\text { nerve }\end{array}$ & $\begin{array}{l}\text { Circumferential tension, } \\
\text { mucosal stroking }\end{array}$ & Page et al,,$^{22} 2005$ \\
\hline & ASIC 3 & $\begin{array}{l}\mathrm{ASIC}^{-/-} \\
\text {mouse }\end{array}$ & $\begin{array}{l}\text { Gastro-esophageal vagal afferent } \\
\text { nerve }\end{array}$ & $\begin{array}{l}\text { Circumferential tension, } \\
\text { mucosal stroking }\end{array}$ & Page et al, 2005 \\
\hline & ASIC & Guinea pig & Esophageal vagal afferent nerve & Circumferential stretch & Zagorodnyuk et al, ${ }^{21} 2003$ \\
\hline & \multirow[t]{2}{*}{$\mathrm{P} 2 \mathrm{X}$} & Ferret & Esophageal vagal afferent nerve & Mucosal stroking & Page et al, ${ }^{19} 2000$ \\
\hline & & Guinea pig & Esophageal vagal afferent nerve & Circumferential stretch & Zagorodnyuk et al, ${ }^{21} 2003$ \\
\hline & Galanin & $\begin{array}{l}\text { Ferret and } \\
\text { mouse }\end{array}$ & $\begin{array}{l}\text { Gastro-esophageal vagal afferent } \\
\text { nerve }\end{array}$ & $\begin{array}{l}\text { Circumferential tension, } \\
\text { mucosal stroking }\end{array}$ & Page et al, 2005 \\
\hline & Ghrelin & $\begin{array}{l}\text { Ferret and } \\
\text { mouse }\end{array}$ & $\begin{array}{l}\text { Gastro-esophageal vagal afferent } \\
\text { nerve }\end{array}$ & $\begin{array}{l}\text { Circumferential tension, } \\
\text { mucosal stroking }\end{array}$ & Page et al, ${ }^{24} 2007$ \\
\hline & Bradykinin & Rat & Thoracic spinal neurons & $\begin{array}{l}\text { Bradykinin }+ \text { esophageal } \\
\text { distension }\end{array}$ & Qin et al, ${ }^{8} 2008$ \\
\hline & \multirow[t]{2}{*}{ mGluR } & Ferret & $\begin{array}{l}\text { Gastro-esophageal vagal afferent } \\
\text { nerve }\end{array}$ & $\begin{array}{l}\text { Circumferential tension, } \\
\text { mucosal stroking }\end{array}$ & Page et al, 2005 \\
\hline & & Mouse & $\begin{array}{l}\text { Gastro-esophageal vagal afferent } \\
\text { nerve }\end{array}$ & $\begin{array}{l}\text { Circumferential tension, } \\
\text { mucosal stroking }\end{array}$ & Slattery et al, 2006 \\
\hline & $\mathrm{GABA}(\mathrm{B})$ & Ferret & $\begin{array}{l}\text { Gastro-esophageal vagal afferent } \\
\text { nerve }\end{array}$ & $\begin{array}{l}\text { Circumferential tension, } \\
\text { mucosal stroking }\end{array}$ & $\begin{array}{l}\text { Page and Blackshaw, } \\
1999\end{array}$ \\
\hline
\end{tabular}


Table 1. Continued.

\begin{tabular}{|c|c|c|c|c|c|}
\hline $\begin{array}{l}\text { Stimulation } \\
\text { category }\end{array}$ & Receptor & $\begin{array}{l}\text { Experimental } \\
\text { species }\end{array}$ & Investigated nerves & Stimulation details & References \\
\hline \multirow[t]{15}{*}{ Chemical } & \multirow[t]{9}{*}{ TRPV1 } & $\begin{array}{l}\mathrm{TRPV1}^{-/-} \\
\text {mouse }\end{array}$ & $\begin{array}{l}\text { Gastro-esophageal vagal afferent } \\
\text { nerve }\end{array}$ & Acid-induced esophagitis & Fujino et al, ${ }^{13} 2006$ \\
\hline & & Rat & $\begin{array}{l}\text { Dorsal root ganglia, Spinal cord, } \\
\text { Nodose ganglia }\end{array}$ & Acid-induced esophagitis & Banerjee et al, ${ }^{14} 2007$ \\
\hline & & Rat & Thoracic spinal neurons & $\mathrm{HCl}$, Capsaicin & Qin et al, ${ }^{8} 2008$ \\
\hline & & Rat & Esophageal vagal afferent nerve & $\mathrm{HCl}$, Capsaicin & Peles et $\mathrm{al}^{28} 2009$ \\
\hline & & Ferret & $\begin{array}{l}\text { Gastro-esophageal vagal afferent } \\
\text { nerve }\end{array}$ & $\mathrm{HCl}$, Capsaicin & $\begin{array}{l}\text { Page and Blackshaw, } \\
1998\end{array}$ \\
\hline & & $\operatorname{Dog}$ & Esophageal vagal afferent nerve & $\mathrm{HCl}$, Capsaicin & Sekizawa et al,$^{30} 1999$ \\
\hline & & Guinea pig & Esophageal vagal afferent nerve & Capsaicin & Yu et al, 2005 \\
\hline & & Human & Esophageal vagal afferent nerve & Capsaicin & Kindt et al, 2009 \\
\hline & & Human & Distal esophageal mucosa & GERD, NERD ${ }^{a}$ & $\begin{array}{l}\text { Guarino et al, }{ }^{60} 2010 \text { and } \\
\text { Shieh et al, }{ }^{32} 2010\end{array}$ \\
\hline & ASIC3 & $\begin{array}{l}\mathrm{ASIC}^{-/-} \\
\text {mouse }\end{array}$ & $\begin{array}{l}\text { Gastro-esophageal vagal afferent } \\
\text { nerve }\end{array}$ & Acid & $\begin{array}{l}\text { Bielefeldt and Davis, }{ }^{12} \\
2008\end{array}$ \\
\hline & \multirow[t]{3}{*}{ Bradykinin } & Ferret & $\begin{array}{l}\text { Gastro-esophageal vagal afferent } \\
\text { nerve }\end{array}$ & Bradykinin & $\begin{array}{l}\text { Page and Blackshaw, } \\
1998\end{array}$ \\
\hline & & Rat & Thoracic spinal neurons & Bradykinin & Qin et al, ${ }^{8} 2008$ \\
\hline & & Opossum & $\begin{array}{l}\text { Esophageal vagal afferent and } \\
\text { Thoracic spinal nerve }\end{array}$ & Bradykinin & Sengupta et al, ${ }^{33} 1992$ \\
\hline & $5-\mathrm{HT}$ & Ferret & $\begin{array}{l}\text { Gastro-esophageal vagal afferent } \\
\text { nerve }\end{array}$ & $5-\mathrm{HT}$ & $\begin{array}{l}\text { Page and Blackshaw, } \\
1998\end{array}$ \\
\hline & $\mathrm{P} 2 \mathrm{X}$ & Guinea pig & Esophageal vagal afferent & $\alpha, \beta$-methylene-ATP & Yu et $\mathrm{al}_{,}^{20} 2005$ \\
\hline
\end{tabular}

a The study demonstrated increased TRPV1 neurons in NERD and/or GERD patients by PCR and/or Western blotting.

TRPV1, transient receptor potential vanilloid 1; TRPA1, transient receptor potential A1; ASIC, acid-sensing ion channel; P2X, a family of ligand-gated ion channels responsive to ATP; mGluR, metabotropic glutamate receptor; iGluR, ionotropic glutamate receptor; GABA, gamma-aminobutyric acid; 5-HT, serotonin; GERD, gastroesophageal reflux disease; NERD, nonerosive reflux disease.

Esophageal sensation is also physiologically important in that it controls esophageal reflexes such as peristalsis and relaxation of the lower esophageal sphincter, which require the sensing of the passage of food or foreign material through the esophagus. ${ }^{34} \mathrm{It}$ has been suggested that such reflexes involve mainly the vagus nerve. ${ }^{35}$ The fact that approximately $80 \%$ to $90 \%$ of vagal nerve fibers are afferent suggests that these physiological reflexes are extremely important to the body.

\section{Pathogenesis of Visceral and Esophageal Hypersensitivity}

Hypersensitivity, which includes both allodynia (perception of stimuli that normally would not be perceived) and hyperalgesia (discomfort or pain greater than would normally be perceived), is a crucial concept in visceral sensation and symptom generation, and has been studied intensively in research on somatic pain. ${ }^{36}$
Hypersensitivity is not necessarily common to all the nociceptive stimuli, ie, a patient may show hypersensitivity to mechanical stimuli but not chemical stimuli. ${ }^{37}$ The pathogenesis of visceral hypersensitivity consists of peripheral hypersensitivity, central hypersensitivity and probably hypersensitivity mediated by psychosocial factors. Peripheral hypersensitivity occurs at peripheral sites, such as esophageal mucosa, and central hypersensitivity occurs in neurons of the spinal cord dorsal horn. We should also note the words of primary and secondary hypersensitivity. A primary hypersensitivity occurs at the site of injury and secondary hypersensitivity accors in the surrounding healthy tissue.

In peripheral tissue, mucosal visceral afferent nerves are activated by physiological neuromediators such as serotonin and cholecystokinin, and such information is utilized for physiological regulation of the gut, including its blood supply. ${ }^{38}$ Once inflammation and/or tissue injury occurs, various noxious stimuli cause the release of inflammatory mediators, such as prosta- 
glandin, bradykinin and serotonin, which transfer the information to the central nervous system. Such inflammatory mediators also reduce the transduction threshold of a variety of cation channels on primary afferent myelinated (A-delta fiber) and unmyelinated (C fiber) neurons, resulting in the phenomenon known as peripheral hypersensitivity. ${ }^{39}$ Peripheral hypersensitivity is considered to be related to hyperalgesia. A variety of peripheral nociceptive receptors are known. Among them, acid-sensing receptors are important in discussing esophageal sensitivity. Acid-sensing receptors that respond to low $\mathrm{pH}$ include TRPV1, ASIC and P2X. The role of TRPV1 has been studied intensively, and it is thought to contribute to formation of visceral hypersensitivity (see Table 1).

Central hypersensitivity is increased excitability of spinal neurons at the central termini of primary afferent neurons. This phenomenon is usually caused by repetitive firing of the afferent neurons and is involved both in allodynia and hyperalgesia. The increased excitability of spinal neurons causes post-translational and transcriptional changes in secondary afferent neurons, namely dorsal horn neurons amplifies the neurological signals. These phenomena are triggered by pre-synaptic release of several neurotransmitters, including substance $\mathrm{P}$, glutamate and brain-derived neurotrophic factor. ${ }^{39}$ These neurotransmitters act on their receptors at post-synaptic sites, which result in phosphorylation of the NMDA (N-methyl-D-aspartate) receptor. This leads to a change in the receptor's kinetics, which results in increased responsiveness to glutamate. In fact, the NMDA receptor is considered to be one of main players in generation of visceral hypersensitivity. ${ }^{40-42}$ It should also be noted that central sensitization causes the excitation of adjacent neurons, which brings secondary hypersensitivity. ${ }^{39}$

Psychosocial factors are known to mediate both peripheral and central hypersensitivity. Stress has received especially great attention because it mediates visceral sensation as well as other physiological functions. ${ }^{43-45}$ Psychiatric disorders in patients with functional GI disease are known, ${ }^{46,47}$ and reports showing that hypnotherapy ${ }^{48}$ and anti-depressants ${ }^{49}$ are effective in such patients clearly demonstrate significant involvement of psychosocial factors. Although not much literature is available on the impact of psychological factors on esophageal sensation, 1 study showed that acute auditory stress enhanced the heartburn symptoms induced by acid exposure in patients with erosive and non-erosive reflux diseases, ${ }^{50}$ and another showed that sleep deprivation enhanced esophageal sensation in response to acid exposure. ${ }^{51}$ Furthermore, it is shown by experimental work that acute stress provokes dilated intercellular spaces (DIS) and mucosal permeability in esophageal mucosa, which may increase esophageal sensation to the acid. ${ }^{52}$ These studies clearly imply a role for emotional and/or physical stress in esophageal sensation. Finally, in a study on the effect of life stress on heartburn symptoms, sustained life stress significantly predicted increased heartburn symptoms. ${ }^{53}$

\section{Esophageal Sensation and Pathogenesis of Heartburn}

Physical, chemical and thermal stimuli in the esophagus are transmitted to the central nervous system. For the defense of the body, it is essential that passage through the esophagus of excessively hot or cold food or beverages and large or hard objects, is sensed. However, unphysiologic stimuli are clinically important. In the esophagus, most such stimuli are caused by unphysiologic reflux of gastric acid, bile acids and other stomach contents, though presence of a certain degree of refluxate is considered physiolosical. Normally, gastric acid does not flow back into the esophagus, but when esophageal reflux of acid occurs due to transient relaxation of the lower esophageal sphincter, increased gastric juice, increased intra-abdominal pressure or other cause, the esophageal mucosa are damaged and symptoms can occur. $^{54}$ This is the condition known as gastroesophageal reflux disease (GERD), and its characteristic symptoms are heartburn and acid regurgitation. ${ }^{55}$ In particular, heartburn has been considered to be a reliable indicator of acid reflux. Surprisingly, however, the mechanism of heartburn onset is far from clear. ${ }^{56}$

In the past, it was thought that the symptoms of heartburn were perceived by the reflux esophagitis (RE) patient through a mechanism in which acid and pepsin penetrated the esophageal mucosa through visible breaks in it, noxious stimuli from those materials spread in the mucosa and directly activated nociceptive receptors in deep layers of the mucosa and the resulting signals were transmitted to the central nervous system. ${ }^{56,57}$ For this mechanism to explain the symptoms, injury to the barrier represented by the surface of the esophageal mucosa must allow the acid or other noxious stimuli to easily penetrate the deep layers of the mucosa. In addition, DIS in esophageal mucosa are a characteristic finding in GERD patients, ${ }^{58}$ and it has been surmised that this dilation allows the noxious stimuli to spread widely and rapidly in the mucosa and easily reach the corresponding nociceptive receptors. ${ }^{56}$ Known acid-sensitive receptors in the GI tract include ASICs, ionotropic purinoceptors and the TRPV1 receptor, which was discussed above, and of those, TRPV1 is re- 
garded as most important in the esophagus. ${ }^{56}$ The finding that treatment of the esophagus of healthy persons with capsaicin results in dose-dependent manifestation of heartburn symptoms suggests that TRPV1 is heavily involved in the development of such symptoms. ${ }^{31}$ In fact, it was shown by immunostaining that TRPV1-positive nerve fibers are increased in inflamed human esophagus, ${ }^{59}$ and it was also reported that esophagitis patients and nonerosive reflux disease (NERD) patients have increased expression of TRPV1 in their esophageal mucosa. ${ }^{60}$

However, it is clear that this acid penetration theory alone cannot possibly explain the mechanism of heartburn. The most obvious contradictory evidence is the existence of patients with NERD. Such patients experience typical symptoms of heartburn even though they do not show mucosal breaks on endoscopic examination. The heartburn symptoms of NERD patients are as severe as those of patients with erosive reflux disease, which includes mucosal damage. NERD patients also suffer quality of life impairment comparable to that of RE patients. NERD patients were shown by 24 hour $\mathrm{pH}$ monitoring to have acid exposure time that is significantly less than that of RE patients. ${ }^{61}$ The fact that acid exposure time was less means that the amount of acid penetrating the esophageal mucosa should be lower. Furthermore, since endoscopically visible mucosal breaks are absent in NERD patients, it seems unlikely that acid penetrates their esophageal mucosa. Besides DIS have been demonstrated in GERD patients, but where DIS occurs in the esophageal mucosa has not still been determined in humans. In the experimental animals, as is shown in Figure 2, the intercellular spaces were dilated in the deep layers of the esophageal mucosa; dilated spaces were not observed on the esophageal surface. There have been a number of reports of such findings. ${ }^{56,58}$ Dilation of the intercellular spaces in upper layers of the esophageal mucosa would be necessary if they were to serve as the route for acid penetration of the esophageal mucosa.

One explanation for the findings that NERD patients have heartburn despite lack of damage to the esophageal mucosa, and in some cases, despite the complete absence of acid reflux is that some heartburn may be caused mechanisms that do not involve acid. A number of reports have shown that mechanical stimuli can cause heartburn; these include a report of heartburn resulting from esophageal distention ${ }^{37}$ and a report that longitudinal contraction of esophageal smooth muscle is related to heartburn symptoms. ${ }^{62}$ Thus there is no doubt that heartburn mediated by mechanoreceptors exists. But mechanoreceptors mediated heartburn is not a majority. How can one explain patients who have

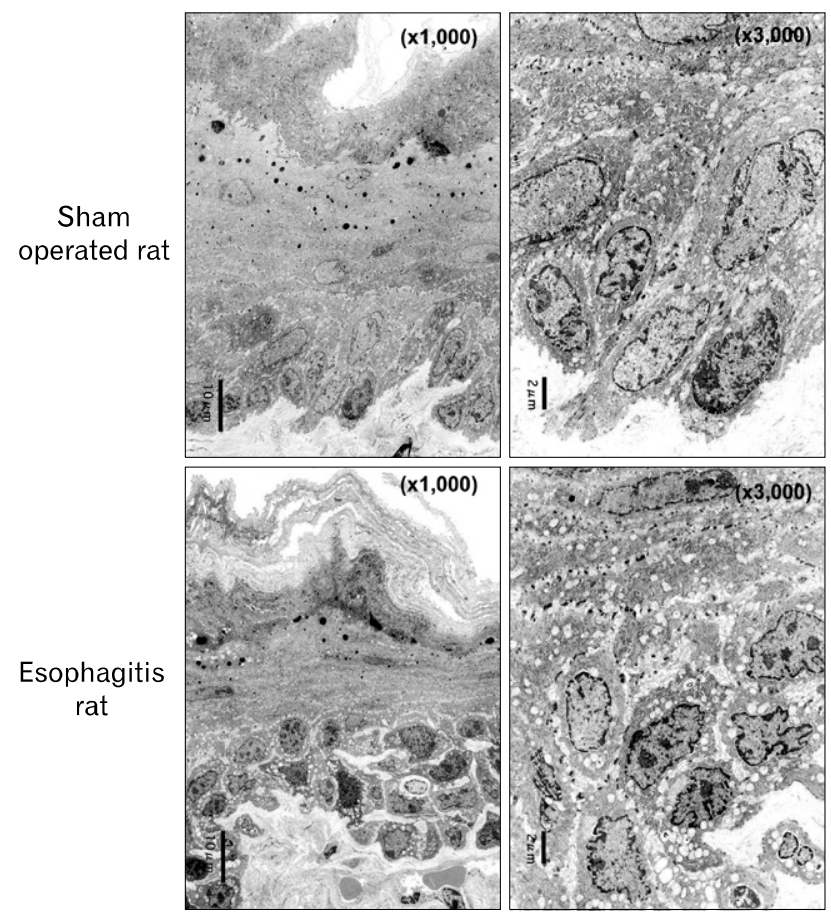

Figure 2. Dilated intercellular spaces (DIS). Electron micrographs of esophageal mucosa from a rat with experimental esophagitis (prepared by method of references 65 and 66) and a sham-operated rat. DIS are clearly visible in the mucosa from the experimental esophagitis rat, and are seen only in the deep layer of the mucosa.

heartburn even though damage to the esophageal mucosa is not observed, reflux is brief, and the reflux acid is weak? We think that failure of the barrier function of the surface of the esophageal mucosa is one mechanism that can explain such patients. NERD patients do not have macroscopic mucosal damage, but they may have invisible mucosal damage. Using a rat model of esophagitis to investigate mucosa with no macroscopic damage, we found that expression of the functional fraction of esophageal mucosal tight-junction proteins, which are thought to determine the permeability of the mucosa, was decreased. ${ }^{63-65}$ This finding suggests that mucosal permeability increases at the stage before manifestation of macroscopic mucosal damage, and this could be related to penetration of the mucosa by noxious stimuli. The cause of the increase in mucosal permeability is unknown, but possible causes include gastric acid, bile acids, pepsin and stress reactions.

According to the conventional acid penetration theory, it was thought that acid and other noxious stimuli directly activate nociceptive receptors, but considering that DIS are seen in deep layers of the esophageal mucosa and in NERD patients with little acid reflux, it may be necessary to approach the causes of heart- 
burn symptoms from a new conceptual framework. That is, the activation of nociceptive receptors by noxious stimuli may be indirect. Indeed, using a rat model of RE, Souza and coworkers ${ }^{66}$ recently showed that rather than acid directly damaging esophageal mucosal epithelium, such damage was mediated by a neuroimmunological mechanism involving secretion of IL-8 and IL$1 \beta$ from the esophageal mucosal epithelium. Rather than being caused by penetration of acid, heartburn symptoms may result from indirect activation of nociceptive receptors by some mechanism. We look forward to future research based on this viewpoint.

\section{Esophageal Hypersensitivity and Diseases (NERD, Functional Heartburn and Non-cardiac Chest Pain)}

Esophageal hypersensitivity is related to a variety of diseases. Heartburn symptoms, fundamentally, are only slightly related to the severity of acid reflux and show large individual differences in severity. Patients with NERD have reflux symptoms in the absence of obvious mucosal breaks and experience heartburn symptoms from acid reflux within the normal range and from reflux of weak acid ( $\mathrm{pH} \geq 4$ ). The pathophysiology of NERD is deeply related to hypersensitivity, with NERD patients sensing low acid reflux more strongly than do erosive GERD patients. ${ }^{67}$ Indeed, the increased sensitivity of NERD patients to acid has been demonstrated by intra-esophageal acid infusion tests. ${ }^{67,68}$ Repeated stimulation of acid-sensitive receptors is thought to be a trigger for the manifestation of hypersensitivity. This idea is supported by the finding that suppression of acid reflux normalizes acid sensitivity. ${ }^{69}$ For this reason, erosive GERD patients also show hypersensitivity to acid to some extent, ${ }^{67,70}$ but the involvement of hypersensitivity is stronger in NERD patients. ${ }^{39}$ Actually, there is a report that sensitivity to mechanical stimuli is decreased in erosive GERD. ${ }^{71}$ In addition, the possibility that factors other than acid are causes of hypersensitivity in NERD patients should be considered. For example, it has been shown in humans that stress is involved in manifestation of hypersensitivity. ${ }^{45,50,51,72}$ Thus, it is thought that in the clinical setting multiple factors combine to cause hypersensitivity, and the mechanism of that is complex.

Patients with functional heartburn have heartburn symptoms despite acid reflux being in the normal range and the timing of the heartburn symptoms being unrelated to the timing of the acid reflux. Whereas NERD is defined by reflux of gastric contents, functional heartburn seems to have different pathophysiology. Function heartburn also is thought to heavily involve esophageal hypersensitivity. Causes of functional heartburn symptoms include stimuli from acid reflux, esophageal distention ${ }^{37}$ and contraction of esophageal smooth muscle, ${ }^{62}$ but hypersensitivity is inferred to be at the root of functional heartburn. Patients with functional heartburn may be hypersensitive to mechanical stimuli as well as to acid. ${ }^{73}$

Patients with non-cardiac chest pain (NCCP) often report retrosternal pain and/or pressure that is indistinguishable from angina pectoris. Whereas the symptoms of functional heartburn are "burning retrosternal discomfort or pain," those of NCCP are "midline chest pain or discomfort that is not of burning quality." ${ }^{, 74}$ Considering the ambiguity of these symptoms, it is unclear whether these 2 conditions really are different. Generally, there are large individual differences in the description of symptoms, and patients do not necessarily describe their symptoms accurately. ${ }^{75}$ While the causes of NCCP have not yet been fully elucidated, most of them are thought to originate in the esophagus. GERD is the most important cause of NCCP, accounting for over $60 \%$ of the cases; other causes include esophageal dysmotility, sustained esophageal contraction, psychological abnormality and visceral hypersensitivity. ${ }^{76,77}$ Saker and coworkers $^{78,79}$ induced a hypersensitive state in the esophagus of NCCP patients and healthy volunteers by continuously instilling acid into the lower esophagus, and they found that the upper esophagus, which had not been exposed to acid, was significantly more sensitive in the NCCP patients than in the healthy volunteers. This finding shows that esophageal hypersensitivity in NCCP patients is caused by enhancement of sensory transfer in the central nervous system, particularly the spinal cord. ${ }^{78,79}$ While NERD, functional heartburn and NCCP are all typical disorders related to hypersensitivity, the idea that visceral hypersensitivity is more involved in the pathophysiology of functional heartburn and NCCP than in that of NERD has been presented. $^{39}$

\section{Silent GERD and Esophageal Hyposensitivity}

Interestingly, it has been known for a long time that some patients do not easily perceive esophageal acid reflux. ${ }^{80}$ Even if obvious $\mathrm{RE}$ is present, such patients do not show the typical reflux symptoms. Since patients normally seek medical care as a result of their experiencing symptoms, the discovery of such silent GERD 
is necessarily incidental. ${ }^{81}$ Consequently, systematic study of the prevalence and pathogenesis of silent GERD is not easy. Still, a recent study in China found that about $30 \%$ to $40 \%$ of patients with RE or Barrett's esophagus were asymptomatic, ${ }^{82}$ indicating that silent GERD is certainly not uncommon. The absence of symptoms is a significant clinical feature because it can delay discovery of severe RE or Barrett's esophagus, or even Barrett's adenocarcinoma, and make it easy to overlook the presence of acid reflux in non-esophageal conditions such as asthma ${ }^{83}$ or idiopathic pulmonary fibrosis. ${ }^{84}$

One must ask, however, whether patients who seem to be asymptomatic really have no symptoms. Silent GERD patients may actually be experiencing some reflux symptoms but not complain of them, perhaps because of lack of understanding that they are symptoms. Or they may have visceral symptoms other than typical reflux symptoms. Therefore, we investigated the symptoms of esophagitis in 275 patients with endoscopically diagnosed RE by using a questionnaire that the patients completed themselves and a health-related quality of life (HRQOL) interview sheet, and we found that $28.5 \%$ of the RE patients had silent GERD with no typical symptoms such as heartburn or regurgitation. Compared to the symptomatic patients, the silent GERD patients had significantly fewer atypical symptoms and higher HRQOL scores (unpublished data). We think that this finding suggests the existence of a specific cohort of patients who do not easily experience symptoms.

In Japan, there are many opportunities to encounter RE incidentally because endoscopic examinations are relatively inexpensive, and asymptomatic persons commonly undergo endoscopic examinations for reasons including gastric cancer screening and comprehensive health examinations (so-called ningen dock). In a study taking advantage of such opportunities, the authors found that smoking, male sex and lower body mass index were independent factors associated with asymptomatic esophagitis. ${ }^{85}$ The pathogenesis of patients with silent GERD is also an interesting topic. Such patients may be hyposensitive to reflux of acid in their esophagus. As very little is known about hyposensitivity in the field of visceral sensitivity, we look forward to future research in this area.

\section{Conclusion}

In this article, we reviewed sensation and/or hypersensitivity in the esophagus and its clinical implication. It is important to learn sensation and/or hypersensitivity for better understanding of the GI symptoms as well as pathogenesis of functional GI disorders. In other words, we will get some clues for understanding individual diversity for symptom perception through investigation of this topic. Hypersensitivity of the esophagus is known to play crucial roles in the pathoegenesis of functional esophageal diseases, including NERD, functional heartburn and NCCP. Furthermore, we should pay attention to the relatively new condition called as "silent GERD." The research for functional esophageal diseases including silent GERD would further shed light on the importance of esophageal sensation and hypersensitivity.

\section{References}

1. Pasricha PJ. Approach to the patient with abdominal pain. In: Yamada T, ed. Textbook of Gastroentrology. 4th ed. Philadelphia: JB Lippincott 2003:781-801.

2. Page AJ, Blackshaw LA. Roles of gastro-oesophageal afferents in the mechanisms and symptoms of reflux disease. Handb Exp Pharmacol 2009;194:227-257.

3. Knowles $\mathrm{CH}$, Aziz Q. Basic and clinical aspects of gastrointestinal pain. Pain 2009;141:191-209.

4. Grundy D, Al-Chaer ED, Aziz Q, et al. Fundamentals of neurogastroenterology: basic science. Gastroenterology 2006;130:13911411.

5. Ozaki N, Gebhart GF. Characterization of mechanosensitive splanchnic nerve afferent fibers innervating the rat stomach. Am J Physiol Gastrointest Liver Physiol 2001;281:G1449-G1459.

6. Ozaki N, Bielefeldt K, Sengupta JN, Gebhart GF. Models of gastric hyperalgesia in the rat. Am J Physiol Gastrointest Liver Physiol 2002;283:G666-G676.

7. Lamb K, Kang YM, Gebhart GF, Bielefeldt K. Gastric inflammation triggers hypersensitivity to acid in awake rats. Gastroenterology 2003;125:1410-1418.

8. Qin C, Farber JP, Foreman RD. Intraesophageal chemicals enhance responsiveness of upper thoracic spinal neurons to mechanical stimulation of esophagus in rats. Am J Physiol Gastrointest Liver Physiol 2008;294:G708-G716.

9. Benham CD, Davis JB, Randall AD. Vanilloid and TRP channels: a family of lipid-gated cation channels. Neuropharmacology 2002; 42:873-888.

10. Caterina MJ, Schumacher MA, Tominaga M, Rosen TA, Levine JD, Julius D. The capsaicin receptor: a heat-activated ion channel in the pain pathway. Nature 1997;389:816-824.

11. Szallasi A, Blumberg PM. Vanilloid (capsaicin) receptors and mechanisms. Pharmacol Rev 1999;51:159-212.

12. Bielefeldt K, Davis BM. Differential effects of ASIC 3 and TRPV1 deletion on gastroesophageal sensation in mice. Am J Physiol Gastrointest Liver Physiol 2008;294:G130-G138.

13. Fujino K, de la Fuente SG, Takami Y, Takahashi T, Mantyh CR. Attenuation of acid induced oesophagitis in VR-1 deficient mice. Gut 2006;55:34-40. 
14. Banerjee B, Medda BK, Lazarova Z, Bansal N, Shaker R, Sengupta $\mathrm{JN}$. Effect of reflux-induced inflammation on transient receptor potential vanilloid one (TRPV1) expression in primary sensory neurons innervating the esophagus of rats. Neurogastroenterol Motil 2007; 19:681-691.

15. Veronesi B, Carter JD, Devlin RB, Simon SA, Oortgiesen M. Neuropeptides and capsaicin stimulate the release of inflammatory cytokines in a human bronchial epithelial cell line. Neuropeptides 1999;33:447-456.

16. Yiangou Y, Facer $\mathrm{P}$, Dyer $\mathrm{NH}$, et al. Vanilloid receptor 1 immunoreactivity in inflamed human bowel. Lancet 2001;357:1338-1339.

17. Yu S, Ouyang A. TRPA1 in bradykinin-induced mechanical hypersensitivity of vagal C fibers in guinea pig esophagus. Am J Physiol Gastrointest Liver Physiol 2009;296:G255-G265.

18. Kondo T, Obata K, Miyoshi K, et al. Transient receptor potential A1 mediates gastric distention-induced visceral pain in rats. Gut 2009; 58:1342-1352.

19. Page AJ, O'Donnell TA, Blackshaw LA. P2X purinoceptor-induced sensitization of ferret vagal mechanoreceptors in oesophageal inflammation. J Physiol 2000;523:403-411.

20. Yu S, Undem BJ, Kollarik M. Vagal afferent nerves with nociceptive properties in guinea-pig oesophagus. J Physiol 2005;563:831-842.

21. Zagorodnyuk VP, Chen BN, Costa M, Brookes SJ. Mechanotransduction by intraganglionic laminar endings of vagal tension receptors in the guinea-pig oesophagus. J Physiol 2003;553:575-587.

22. Page AJ, Brierley SM, Martin CM, et al. Different contributions of ASIC channels 1a, 2, and 3 in gastro-intestinal mechano-sensory function. Gut 2005;54:1408-1415.

23. Page AJ, Slattery JA, O'donnell TA, Cooper NJ, Young RL, Blackshaw LA. Modulation of gastro-oesophageal vagal afferents by galanin in mouse and ferret. J Physiol 2005;563:809-819.

24. Page AJ, Slattery JA, Milte C, et al. Ghrelin selectively reduces mechanosensitivity of upper gastrointestinal vagal afferents. Am J Physiol Gastrointest Liver Physiol 2007;292:G1376-G1384.

25. Page AJ, Young RL, Martin CM, et al. Metabotropic glutamate receptors inhibit mechanosensitivity in vagal sensory neurons. Gastroenterology 2005;128:402-410.

26. Slattery JA, Page AJ, Dorian CL, Brierley SM, Blackshaw LA. Potentiation of mouse vagal afferent mechanosensitivity by ionotropic and metabotropic glutamate receptors. J Physiol 2006;577:295-306.

27. Page AJ, Blackshaw LA. GABA(B) receptors inhibit mechanosensitivity of primary afferent endings. J Neurosci 1999;19:8597-8602.

28. Peles S, Medda BK, Zhang Z, et al. Differential effects of transient receptor vanilloid one (TRPV1) antagonists in acid-induced excitation of esophageal vagal afferent fibers of rats. Neuroscience 2009;161:515-525.

29. Page AJ, Blackshaw LA. An in vitro study of the properties of vagal afferent fibres innervating the ferret oesophagus and stomach. J Physiol 1998;512:907-916.

30. Sekizawa S, Ishikawa T, Sant'Ambrogio FB, Sant'Ambrogio G. Vagal esophageal receptors in anesthetized dogs: mechanical and chemical responsiveness. J Appl Physiol 1999;86:1231-1235.

31. Kindt S, Vos R, Blondeau K, Tack J. Influence of intra-oesophageal capsaicin instillation on heartburn induction and oesophageal sensitivity in man. Neurogastroenterol Motil 2009;21:1032-e82.

32. Shieh KR, Yi CH, Liu TT, et al. Evidence for neurotrophic factors associating with TRPV1 gene expression in the inflamed human esophagus. Neurogastroenterol Motil 2010;22:971-977.

33. Sengupta JN, Saha JK, Goyal RK. Differential sensitivity to bradykinin of esophageal distension-sensitive mechanoreceptors in vagal and sympathetic afferents of the opossum. J Neurophysiol 1992;68: 1053-1067.

34. Christensen J. Origin of sensation in the esophagus. Am J Physiol 1984;246:G221-G225.

35. Clerc N, Mei N. Vagal mechanoreceptors located in the lower oesophageal sphincter of the cat. J Physiol 1983;336:487-498.

36. Lewin GR, Moshourab R. Mechanosensation and pain. J Neurobiol 2004;61:30-44.

37. Fass R, Naliboff B, Higa L, et al. Differential effect of long-term esophageal acid exposure on mechanosensitivity and chemosensitivity in humans. Gastroenterology 1998;115:1363-1373.

38. Costa M, Brookes SH, Zogorodnyuk V. How many kinds of visceral afferents? Gut 2004;53(suppl 2):ii1-ii4.

39. Knowles $\mathrm{CH}$, Aziz Q. Visceral hypersensitivity in nonerosive reflux disease. Gut 2008;57:674-683.

40. Banerjee B, Medda BK, Zheng Y, et al. Alterations in N-methyl-D-aspartate receptor subunits in primary sensory neurons following acid-induced esophagitis in cats. Am J Physiol Gastrointest Liver Physiol 2009;296:G66-G77.

41. Willert RP, Delaney C, Kelly K, Sharma A, Aziz Q, Hobson AR. Exploring the neurophysiological basis of chest wall allodynia induced by experimental oesophageal acidification - evidence of central sensitization. Neurogastroenterol Motil 2007;19:270-278.

42. Willert RP, Woolf CJ, Hobson AR, Delaney C, Thompson DG, Aziz $\mathrm{Q}$. The development and maintenance of human visceral pain hypersensitivity is dependent on the N-methyl-D-aspartate receptor. Gastroenterology 2004;126:683-692.

43. Geeraerts B, Vandenberghe J, Van Oudenhove L, et al. Influence of experimentally induced anxiety on gastric sensorimotor function in humans. Gastroenterology 2005;129:1437-1444.

44. van den Wijngaard RM, Klooker TK, Welting O, et al. Essential role for TRPV1 in stress-induced (mast cell-dependent) colonic hypersensitivity in maternally separated rats. Neurogastroenterol Motil 2009;21:1107-e94.

45. Mertz H. Review article: visceral hypersensitivity. Aliment Pharmacol Ther 2003;17:623-633.

46. Aro P, Talley NJ, Ronkainen J, et al. Anxiety is associated with uninvestigated and functional dyspepsia (Rome III criteria) in a Swedish population-based study. Gastroenterology 2009;137:94-100.

47. Van Oudenhove L, Vandenberghe J, Geeraerts B, et al. Determinants of symptoms in functional dyspepsia: gastric sensorimotor function, psychosocial factors or somatisation? Gut 2008;57: 1666-1673.

48. Calvert EL, Houghton LA, Cooper P, Morris J, Whorwell PJ. Long-term improvement in functional dyspepsia using hypnotherapy. Gastroenterology 2002;123:1778-1785.

49. Hojo M, Miwa H, Yokoyama T, et al. Treatment of functional dyspepsia with antianxiety or antidepressive agents: systematic review. J Gastroenterol 2005;40:1036-1042.

50. Fass R, Naliboff BD, Fass SS, et al. The effect of auditory stress on perception of intraesophageal acid in patients with gastroesophageal reflux disease. Gastroenterology 2008;134:696-705.

51. Schey R, Dickman R, Parthasarathy S, et al. Sleep deprivation is hy- 
peralgesic in patients with gastroesophageal reflux disease. Gastroenterology 2007;133:1787-1795.

52. Farré R, De Vos R, Geboes K, et al. Critical role of stress in increased oesophageal mucosa permeability and dilated intercellular spaces. Gut 2007;56:1191-1197.

53. Naliboff BD, Mayer M, Fass R, et al. The effect of life stress on symptoms of heartburn. Psychosom Med 2004;66:426-434.

54. Kahrilas PJ, Lee TJ. Pathophysiology of gastroesophageal reflux disease. Thorac Surg Clin 2005;15:323-333.

55. Vakil N, van Zanten SV, Kahrilas P, Dent J, Jones R; Global Consensus Group. The Montreal definition and classification of gastroesophageal reflux disease: a global evidence - based consensus. Z Gastroenterol 2007;45:1125-1140.

56. Ang D, Sifrim D, Tack J. Mechanisms of heartburn. Nat Clin Pract Gastroenterol Hepatol 2008;5:383-392.

57. Barlow WJ, Orland RC. The pathogenesis of heartburn in nonerosive reflux disease: a unfying hypothesis. Gastroenterology 2005; 128:771-778.

58. van Malenstein H, Farré R, Sifrim D. Esophageal intercellular spaces and nonerosive reflux disease. Am J Gastroenterol 2008;103: 1021-1028.

59. Matthews PJ, Aziz Q, Facer P, Davis JB, Thompson DG, Anand P. Increase capsaicin receptor TRPV1 nerve fibres in the inflamed human oesophagus. Eur J Gastroenterol Hepatol 2004;16:897-902.

60. Guarino MP, Cheng L, Ma J, et al. Increased TRPV1 gene expression in esophageal mucosa of patients with non-erosive and erosive reflux disease. Neurogastroenterol Motil 2010;22:746-751.

61. Bredenoord AJ, Hemmink GJ, Smout AJ. Relationship between gastro-oesophageal reflux pattern and severity of mucosal damage. Neurogastroenterol Motil 2009;21:807-812.

62. Pehlivanov N, Liu J, Mittal RK. Sustained esophageal contraction: a motor correlate of heartburn symptom. Am J Physiol Gastrointest Liver Physiol 2001;281:G743-G751.

63. Asaoka D, Miwa H, Hirai S, et al. Altered localization and expression of tight-junction proteins in a rat model with chronic acid reflux esophagitis. J Gastroenterol 2005;40:781-790.

64. Miwa H, Oshima T, Sakurai J, et al. Experimental oesophagitis in the rat is associated with decreased voluntary movement. Neurogastroenterol Motil 2009;21:296-303.

65. Miwa H, Koseki J, Oshima T, et al. Rikkunshito, a traditional Japanese medicine, may relieve abdominal symptoms in rats with experimental esophagitis by improving the barrier function of epithelial cells in esophageal mucosa. J Gastroenterol 2010;45:478-487.

66. Souza RF, Huo X, Mittal V, et al. Gastroesophageal reflux might cause esophagitis through a cytokine-mediated mechanism rather than caustic acid injury. Gastroenterology 2009;137:1776-1784.

67. Miwa H, Minoo T, Hojo M, et al. Oesophageal hypersensitivity in Japanese patients with non-erosive gastro-oesophageal reflux diseases. Aliment Pharmacol Ther 2004;20(suppl 1):112-117.

68. Nagahara A, Miwa H, Minoo T, et al. Increased esophageal sensitivity to acid and saline in patients with nonerosive gastro-esophageal reflux disease. J Clin Gastroenterol 2006;40:891-895.

69. Marrero JM, Caestecker JS, Maxweel JD. Effect of famotidine on oesophageal sensitivity in gastro-oesophageal reflux disease. Gut 1994;35:447-450.

70. Hong SJ, Ko BM, Jung IS, et al. Relevance of ineffective esophageal motility and hyperactive acid sensitization in patients with gastroesophageal reflux. J Gastroenterol Hepatol 2007;22:1662-1665.

71. Drewes AM, Reddy H, Pedersen J, Funch-Jensen P, Gregersen H, Arendt-Nielsen L. Multimodal pain stimulations in patients with grade B oesophagitis. Gut 2006;55:926-932.

72. Bradley LA, Richter JE, Pulliam TJ, et al. The relationship between stress and symptoms of gastroesophageal reflux: the influence of psychological factors. Am J Gastroenterol 1993;88:11-19.

73. Rodriguez-Stanley S, Robinson M, Earnest DL, Greenwood-Van Meerveld B, Miner PB Jr. Esophageal hypersensitivity may be a major cause of heartburn. Am J Gastroenterol 1999;94:628-631.

74. Galmiche JP, Clouse RE, Bálint A, et al. Functional esophageal disorders. Gastroenterology 2006;130:1459-1465.

75. Manabe N, Haruma K, Hata J, Kamada T, Kusunoki H. Differences in recognition of heartburn symptoms between Japanese patients with gastroesophageal reflux, physicians, nurses, and healthy lay subjects. Scand J Gastroenterol 2008;43:398-402.

76. Richter JE, Bradley LA, Castell DO. Esophageal chest pain: current controversies in pathogenesis, diagnosis, and therapy. Ann Intern Med 1989;110:66-78.

77. Sharma A, Aziz Q. Sensory testing in noncardiac chest pain. In: Fass R, Eslick G, eds. Noncardiac chest pain. San Diego: Plural publishing 2007: 59-81.

78. Sarkar S, Aziz Q, Woolf CJ, Hobson AR, Thompson DG. Contribution of central sensitization to the development of non-cardiac chest pain. Lancet 2000;356:1154-1159.

79. Sarkar S, Hobson AR, Furlong PL, Woolf CJ, Thompson DG, Aziz Q. Central neural mechanisms mediating human visceral hypersensitivity. Am J Physiol Gastrointest Liver Physiol 2001;281: G1196-G1202.

80. Fass R, Sampliner RE, Mackel C, McGee D, Rappaport W. Ageand gender-related differences in 24-hour esophageal $\mathrm{pH}$ monitoring of normal subjects. Dig Dis Sci 1993;38:1926-1928.

81. Fass R, Dickman R. Clinical consequences of silent gastroesophageal reflux disease. Curr Gastroenterol Rep 2006;8:195-201.

82. Peng S, Cui Y, Xiao YL, et al. Prevalence of erosive esophagitis and Barrett's esophagus in the adult Chinese population. Endoscopy 2009;41:1011-1017.

83. Harding SM, Guzzo MR, Richter JE. The prevalence of gastroesophageal reflux in asthma patients without reflux symptoms. Am J Respir Crit Care Med 2000;162:34-39.

84. Pashinsky YY, Jaffin BW, Litle VR. Gastroesophageal reflux disease and idiopathic pulmonary fibrosis. Mt Sinai J Med 2009;76:24-29.

85. Nozu T, Komiyama H. Clinical characteristics of asymptomatic esophagitis. J Gastroenterol 2008;43:27-31. 